\title{
SÄILYTYSAINEIDEN KÄYTÖSTÄ PORKKANAN VARASTOIMISESSA
}

\author{
JaAkKo Mukula. \\ Maatalouskoelaitoksen kasvitautiosasto, Tikkurila.
}

Saapunut 23. 5. 1950

Porkkanat ovat säilytyksen aikana varsin alttiita tuhosienien vahingoille. Sadosta mädäntyy varastossa usein $10-20 \%$, eivätkä sellaisetkaan tappioluvut kuin $25-100 \%$ ole harvinaisia. Porkkanan varastoimiskysymys onkin sen vuoksi kauan ollut eri maissa vilkkaan tutkimuksen kohteena. LAURITzEN (4) ja eräät muut tutkijat ovat esittäneet, että tuhosienien torjumiseksi porkkanavaraston lämpötilan tulisi olla $0-2^{0} \mathrm{C}$ ja ilman suhteellisen kosteuden $90-95 \%$. Tällöinkään ei tuhosienien kasvu esty täydellisesti, mutta niiden aiheuttamat tappiot jäävät verraten vähäisiksi. Käytännössä porkkanavaraston lämpötilan pitäminen näin alhaisena tuottaa vaikeuksia ellei ole käytettävissä koneellisia lämmönsäätölaitteita. Sitäpaitsi porkkanat säilytetään usein perunoiden kanssa samassa varastossa, jolloin lämpötila täytyy pitää yli $2^{0} \mathrm{C}$ :ssa.

Maatalouskoelaitoksen kasvitautiosastolla Tikkurilassa suoritettiin vv. 19481950 porkkanan varastoimiskokeita F u s a r e x-nimisellä säilytysaineella, joka on tarkoitettu käytettäväksi perunan varastoimisessa perunoiden tuhosienivahinkojen ja itämisen estämiseen $(1,2)$. Aineen valmistaja suosittelee sitä myös juurikasveille, vaikkakaan kirjoittaja ei ole havainnut kirjallisuudessa tietoja sen käyttökelpoisuudesta näille kasveille. Fusarex on jauhemainen valmiste ja sisältää tehoavana aineena $3 \%$ tetrakloorinitrobensolia. Suositeltu käyttömäärä $0.5 \mathrm{~kg} 100 \mathrm{~kg}$ kohti. Alustavasti kokeiltiin myös B elvitan K-nimisen, niinikään jauhemaisen perunansäilytysaineen vaikutusta porkkanan säilyvyyteen. Belvitan K:ta suositellaan käytettäväksi $0.2 \mathrm{~kg} 100 \mathrm{~kg}$ kohti (3). Sen sisältämien aineiden kemiallisesta koostumuksesta valmistaja ei ole toistaiseksi antanut tietoja.

Käytettyjen säilytysaineiden valmistajat ja edustajat ovat:

Fusarex: Valmistaja Bayer Products Ltd., London. Edustaja Suomessa S. G. Nieminen Oy, Helsinki. - Belvitan K: Valmistaja Farbenfabriken Bayer, Leverkusen. Edustaja Suomessa Berner \& Co Oy Sören, Helsinki. 
Kokeet suoritettiin varastoitujen kasvinosien säilyvyyttä koskevien tutkimuksien yhteydessä, joita varten Suomen Osuuskauppojen Keskuskunta rl. oli myöntänyt kasvitautiosastolle apurahan. Käytetyt varastosuojat olivat melko kuivia ja verraten voimakkaasti tuuletettuja. Ilman suhteellinen kosteus vaihteli koepaikoissa $70-95 \%$ ja lämpötila $2-6^{0} \mathrm{C}$. Säilytysaineet sekoitettiin valmistajien suosittelemissa käyttömäärissä porkkanoiden joukkoon mahdollisimman tasaisesti. Fusarexin vaikutusta säilyvyyteen tutkittiin erikseen ehjillä, porkkanakärpäsen (Psila rosae FABR.) toukkien vioittamilla ja muulla tavoin mekaanisesti vioittuneilla (katkaistuilla) porkkanoilla. Nämä sijoitettiin varastossa laatikoihin, osa pelkästään, osa turvepehkun ja osa hiekan joukkoon sekoitettuna. Säilytysaika oli n. 6 kuukautta. Kokeiden tarkastukset suoritettiin kahdesti: keskellä talvea n. 3 kuukauden säilytyksen jälkeen ja keväällä varastoimisen päättyessä. Kummallakin tarkastuskerralla porkkanat punnittiin ja tuhosienien turmelemat yksilöt poistettiin.

Säilytysolosuhteet ja kokeiden järjestely olivat seuraavat:

K o e 1. Kokeiltiin Fusarexin vaikutusta säilyvyyteen pelkästään, turvepehkun kanssa ja hiekan kanssa varastoiduilla porkkanoilla. Turvepehku ja hiekka olivat kokeen alussa ilmakuivia. Edellistä käytettiin $4 \mathrm{~kg}$ ja jälkimmäistä $100 \mathrm{~kg} 100 \mathrm{~kg}$ kohti. Ne sekoitettiin tasaisesti porkkanoiden joukkoon. Säilytys tapahtui tiivisseinäisissä, $65 \times 50 \times 15 \mathrm{~cm}$ :n suuruisissa laatikoissa. Nämä sijoitettiin 4-kerroksiseen riviin, siten että viereisten laatikoiden väli oli $5-7 \mathrm{~cm}$ ja päällekkäin olevien $1.5 \mathrm{~cm}$. Porkkanalajike Nantes. Koe-erien suuruus $20 \mathrm{~kg}$. Kerrannaisia pelkästään säilytetyistä koejäsenistä 4, turvepehkun ja hiekan kanssa säilytetyistä 2. Säilytysaika 18. 10,-28. 1.—10. 4. Varaston keskilämpötila $18.10 .-28.1 .+5.2^{\circ}$ ja $28.1 .-10.4 .+3.2^{\circ}$.

K o e 2. Kokeiltiin Fusarexin vaikutusta säilyvyyteen Lontoon-tori-porkkanoilla. Säilytys tapahtui tiivisseinäisissä laatikoissa, jotka sijoitettiin varastoon samaan tapaan kuin edellisessä kokeessa. Koe-erien suuruus $20 \mathrm{~kg}$. Kerrannaisia kussakin koejäsenessä kokeen alussa 6. Talvella suoritetun tarkastuksen jälkeen yhdistettiin käsittelemättömät kerrannaiset $3: k s i$ ja käsitellyt $5: k s i$. Säilytysaika 1. 11.-1. 2.-1. 5. Varaston keskilämpötila 1. 11.-1. $2 .+5.0^{\circ}$ ja 1. 2.-1.5. $+3.0^{\circ}$.

K o e 3. Kokeiltiin Fusarexin vaikutusta säilyvyyteen erikseen ehjillä, porkkanakärpäsen toukkien vioittamilla ja katkaistuilla porkkanoilla. Säilytys tapahtui harvaseinäisissä, $30 \times 30 \times 15 \mathrm{~cm}$ :n suuruisissa laatikoissa. Nämä sijoitettiin pinoon, jossa viereisten laatikoiden väli oli $10 \mathrm{~cm}$ ja päällekkäin olevien $15 \mathrm{~cm}$. Porkkanalajike Lontoon tori. Koe-erien suuruus n. $4 \mathrm{~kg}$ (=50 porkkanaa). Kerrannaisia 4. Säilytysaika 2. 10.-2. 1. -2. 4. Varaston keskilämpötila 2. 10.-2. 1. +5.5 ja 2. 1.2. $4 .+2.8^{\circ}$.

K o e 4. Kokeiltiin alustavasti Belvitan K:n vaikutusta säilyvyyteen Lontoon-tori-porkkanoilla. Säilytys tapahtui tiivisseinäisissä laatikoissa. Koe-erien suuruus $20 \mathrm{~kg}$. Ei kerrannaisia. Säilytysaika 1. 12.-1. 3.-1. 6. Varaston keskilämpötila 1. 12.-1. 3. +2. $7^{\circ}$. ja 1. 3. - 1. 6. +6.2 .

Fusarex esti ti ivissein ä isiss ä laatikoissa (kokeet 1 ja 2) tehokkaasti porkkanoiden mädäntymistä (vrt. kuva 1, s. 89). Aineella käsitellyistä porkkanoista tuhosienet turmelivat vain $6-15 \%$, kun sen sijaan käsittelemättömistä mädäntyi 25-71\%. Myös Belvitan K antoi alustavassa kokeessa (koe 4) samansuuntaisen tuloksen. Sen sijaan turvepehku ja hiekka vaikuttavat vain vähäisessä määrin porkkanoiden mädäntymistä ehkäisevästi. H a r v a s e i n ä i s i s s ä laatikoissa (koe 3) Fusarex paransi säilytyskauden alkupuolella ehjien ja katkaistujen porkkanoiden säilyvyyttä, mutta ei porkkanakärpäsen toukkien vioittamien. Säilytyskauden loppupuolella se ei enää estänyt mädäntymistä missään koeryhmässä. Tulokset selviävät lähemmin oheisesta taulukosta. 


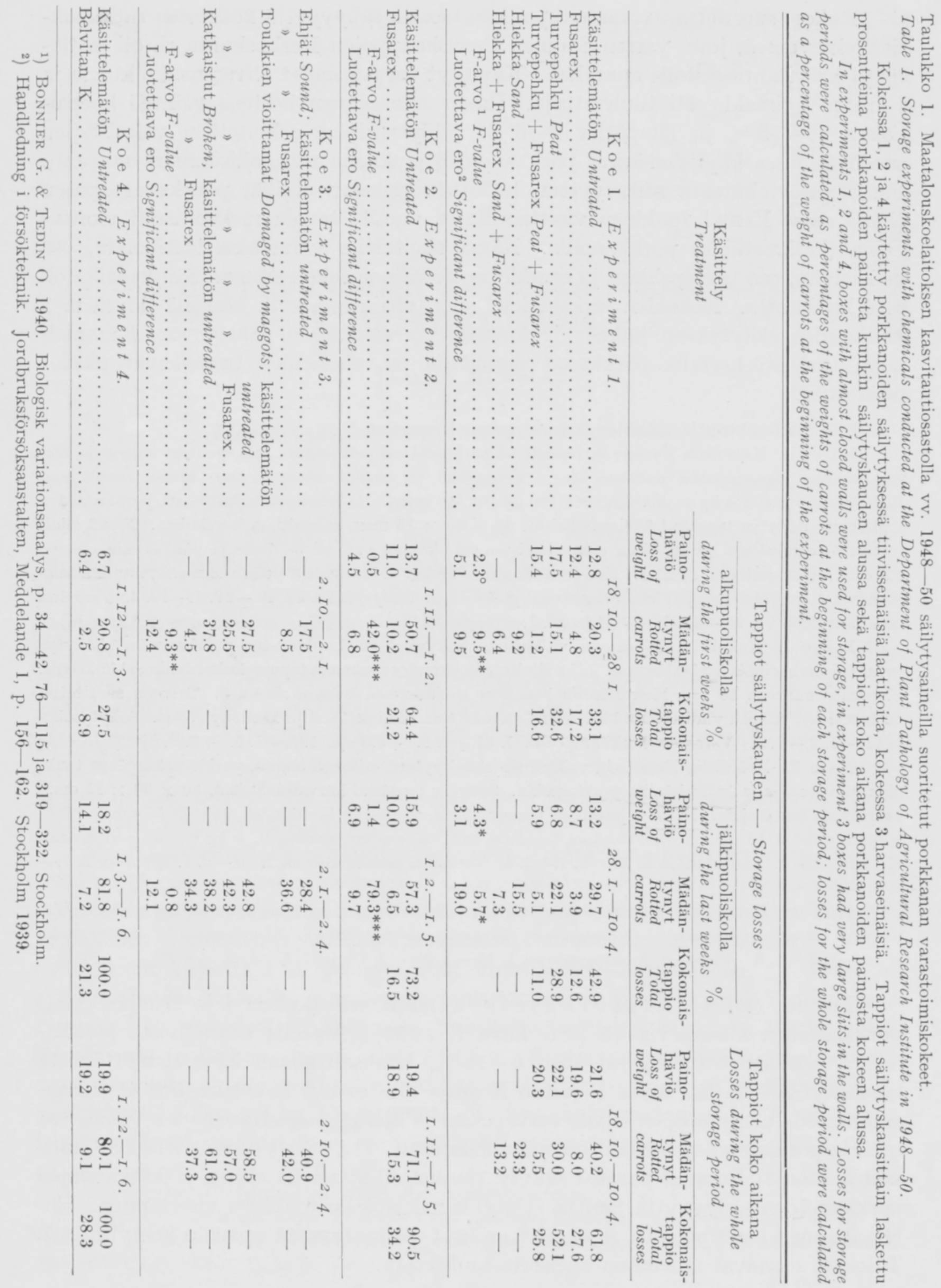



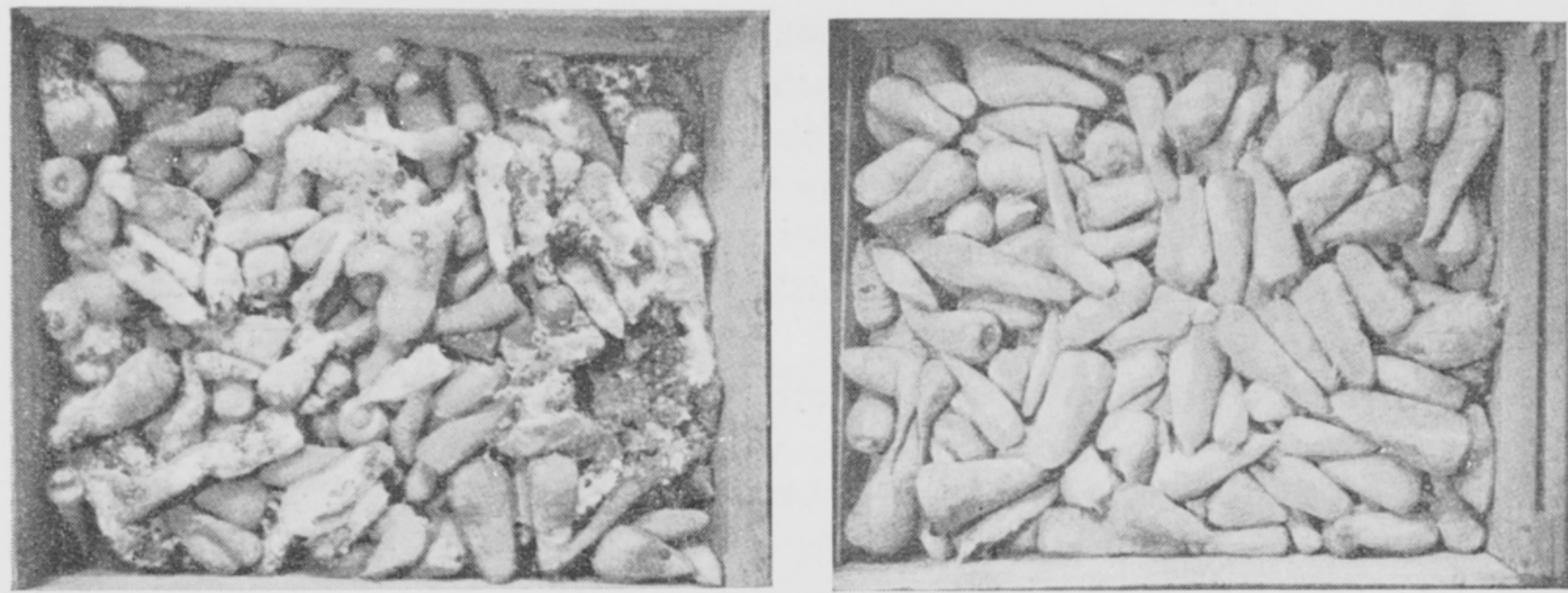

Kuva 1. Vasemmalla käsittelemättömiä, oikealla Fusarexilla käsiteltyjä porkkanoita 3 kuukauden säilytyksen jälkeen. Botrytis- ja Sclerotinia-sienet turmelleet n. $50 \%$ käsittelemättömistä porkkanoista.

Figure 1. On the left untreated, on the right Fusarex-treated carrots after 3 months' storage. About $50 \%$ of untreated carrots damaged by $B$ ot $r y t i s$ and Sclerotinia.
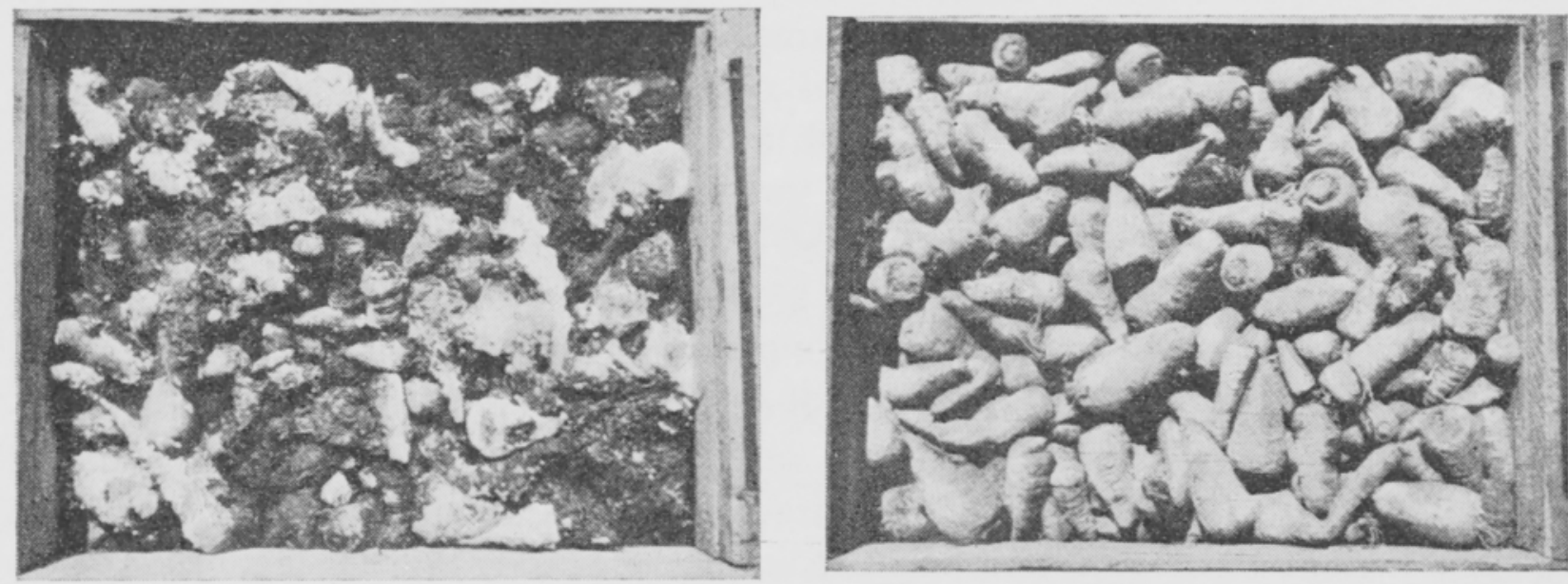

Kuva 2. Vasemmalla käsittelemättömiä, oikealla Belvitan K:lla käsiteltyjä porkkanoita 6 kuukauden säilytyksen jälkeen. Botrytis- ja Sclerotinia-sienet turmelleet käsittelemättömät porkkanat täydellisesti.

Figure 2. On the left untreated, on the right carrots treated after 6 months' storage. All untreated carrots damaged by $B$ otrytis and Sclerotinia.

Mädäntymisen aiheuttajana esiintyi kokeessa 1 pääasiallisesti $\mathrm{h}$ a r ma ah o m e, Botrytis sp. Kokeissa 2 ja 4 tavattiin sen ohella runsaasti p a h k a mä t ää, Sclerotinia sclerotiorum (LIB.) DE BARY. Kumpikin sieni muodosti käsittelemättömien porkkanoiden pinnalle rihmastoa ja pahkoja (kuvat 1 ja 2). Sikäli kuin näitä sieniä tavattiin Fusarexilla ja Belvitan K:lla käsitellyissä porkkanoissa, ne kasvoivat porkkanoiden pinnan alla mädättäen nämä sisältä päin. Kokeessa 3 esiintyivät mädäntymisen aiheuttajina Fusarium avenaceum (FrIEs) SACC., Botrytis sp. ja Stempylium radicinum (M. DR. \& E.) NEERG., näistä ensiksi mainittu yleisimpänä. Fusarium-sieneen ei Fusarex tässä näyttänyt paljoakaan tehonneen. - Muiden kokeissa tavattujen sienien merkitys mädäntymisen aiheuttajana oli vähäinen. 
Painohäviö oli varsinkin säilytyskauden jälkipuoliskolla käsittelemättömissä porkkanoissa jonkin verran suurempi kuin säilytysaineilla käsitellyissä. Tämä lienee johtunut pääasiallisesti siitä, että tuhosienien turmelemista porkkanoista vesi on päässyt haihtumaan helpommin kuin terveistä. Säilytys turvepehkun kanssa vaikutti painohäviöön aluksi edistävästi, myöhemmin ehkäisevästi. Ilmeisesti turvepehku imi ensin porkkanoista vettä, mutta myöhemmin kostuttuaan esti haihtumista.

Kokeet 1 ja 2 osoittavat, että Fusarex estää määrätyissä olosuhteissa tehokkaasti porkkanoiden mädäntymistä. Se vaikuttaa ehkäisevästi ainakin Botrytisja Sclerotinia-sienten kehittymiseen, jos käsittely suoritetaan ennen kuin mädäntyminen on päässyt alkamaan. Samanlainen ominaisuus näyttää olevan myös Belvitan K:lla (koe 4). Kokeessa 3, jossa käytettiin melko avonaisia laatikoita ja verraten pieniä koe-eriä, on Fusarexin teho ehjissä ja katkaistuissa porkkanoissa ollut lyhytaikainen, ja porkkanakärpäsen toukkien vioittamissa porkkanoissa se ei ole vaikuttanut tuhosieniin lainkaan. Mahdollista on, että Fusarex-valmisteesta on laatikoiden avonaisuuden ja koe-erien pienuuden vuoksi päässyt haihtumaan sieniin tehoavaa ainetta. Tällaiselle käsitykselle antavat tukea aikaisemmin Englannissa Fusarexilla suoritetut kokeet varastoidulla perunalla $(1,2)$. Myös kokeessa 3 olleen porkkanaerän erilainen tuhosienikoostumus on saattanut olla syynä toisenlaiseen tulokseen kuin kokeissa 1 ja 2. Mitä tulee porkkanakärpäsen toukkien vioittamien porkkanoiden säilyvyyteen, on ymmärrettävää, ettei Fusarex estä niiden mädäntymistä ainakaan yhtä tehokkaasti kuin ehjien. Tuhosienien itiöt saattavat nimittäin tunkeutua toukkien syömiin käytäviin jo kasvukauden aikana, jolloin saastutus on tapahtunut ennen varastoonpanoa.

Fusarexin käytöstä porkkanan säilytyksessä on eräissä helsinkiläisissä elintarvikekauppaa harjoittavissa liikkeissä saatu edullisia kokemuksia. Alla mainitut liikkeet ovat vv. 1948-50 käsitelleet varastoissaan Fusarexilla seuraavan suuruisia porkkanaeriä: Helsingin kaupungin Elintarvikekeskus $128.000 \mathrm{~kg}$, Kesko Oy $10.000 \mathrm{~kg}$ ja Oy Tuotevälitys $5.000 \mathrm{~kg}$.

Porkkanat on tapana helsinkiläisten liikkeiden varastoissa sijoittaa avonaisiin laareihin, $20 \stackrel{\bullet}{\bullet} 70 \mathrm{~cm}$ paksuihin kerroksiin. Varastosuojien lämpötila vaihtelee $2-6^{\circ} \mathrm{C}$. $1-2$ kuukauden kuluttua varastoonpanosta porkkanat alkavat tavallisesti po. varastoissa mädäntyä niin pahoin, että niiden säilytys täytyy keskeyttää. Lajittelemalla tautiset yksilöt eroon voidaan vain vähäisessä määrin hidastaa mädäntymisilmiön kehittymistä.

Liikkeet ovat ilmoittaneet Fusarexin ratkaisevasti parantaneen porkkanoiden säilyvyyttä. Jos nämä ovat varastoon pantaessa olleet tautivapaita, niin tuhosienien aiheuttamat tappiot ovat supistuneet $0-5 \%$ :ksi vielä niin pitkän kuin 3-6 kuukauden säilytysajan jälkeen. Tappiot ovat kuitenkin muodostuneet huomattavasti suuremmiksi, $10-20 \%: k s i$, jos osa porkkanoista on varastoon partaessa ollut vaikkapa vain lievästikin tuhosienien saastuttamaa. Fusarexilla käsitellyt porkkanat on myyty kuluttajille Helsingissä. Tähän asti ei ole ilmoitettu niiden olleen epäterveellisiä tai maultaan huonompia kuin käsittelemättömät pork- 
kanat. Myös kasvitautiosastolla suoritetuissa makukokeissa ei voitu havaita Fusarexin enempää kuin Belvitan K:nkaan vaikuttaneen haitallisesti porkkanoiden makuun.

\author{
KIRJALLISUUTTA.
}

(1) Anon. 1948. Chemical prevention of potato dry rot disease. Nature, 162, p. 843. London.

(2) - - 1949. The protection of stored seed potatoes. World Crops, 1, 2, p. 63-65. Ref. Review of Applied Mycology, 1949, 28, p. 640-641.

(3) Grewe, Ferdinant 1949. Über die Wirkungsweise von Belvitan K unter besonderer Berücksichtigung seiner fungistatischen Wirksamkeit. Höfchen-Briefe für Wissenschaft und Praxis, 2, 1, p. 37-48. Leverkusen.

(4) Lauritzen, J. I. 1932. Development of certain storage and transit diseases of carrot. Journal Agric. Research, 44, p. $860-912$.

S U M M A R Y.

ON CHEMICAL PREVENTION OF STORAGE ROT IN CARROTS

JaAkкo Mukula.

Agricultural Research Institute, Department of Plant Pathology, Tikkurila.

In the years 1948 - 1950, experiments of carrot storage were conducted with Fusarex, a chemical manufactured by Bauer Products Ltd., at the Department of Plant Pathology of Agricultural Research Institute. Fusarex is prepared for use in potato storage, to prevent rotting and sprouting (3,4). The manufacturer also recommends it for root crops, though the writer of this paper has not found any information in literature about its usefulness for this purpose. Fusarex is a chemical in dust form, and as effective ingredient it contains $3 \%$ of tetrachloronitrobenzene. The recommended dosage is about $0.5 \mathrm{~kg}$. per $100 \mathrm{~kg}$. Preliminary experiments on carrots were also conducted with Belvitan $\mathrm{K}$, manufactured by Farbenfabriken Bayer. Like Fusarex, this chemical is used in dust form and it is prepared for use in potato storage. The recommended dosage of Belvitan $\mathrm{K}$ is $0.2 \mathrm{~kg}$. per $100 \mathrm{~kg}$. (1). No information concerning its ingredients is available.

The storage sheds used in the experiments were fairly dry and well ventilated. The relative moisture of air varied from 70 to $95 \%$, temperature from 2 to $6^{\circ} \mathrm{C}$. The chemicals were scattered over the carrots as uniformly as possible, in dosages recommended by the manufacturer. The effect of Fusarex was separately tested on sound carrots, on carrots damaged by maggots of Psila rosae FABR., and on broken carrots. In sheds the carrots were placed in boxes, in some cases mixed with peat or sand. The walls of the boxes were either almost closed or had very large slits in them. The former boxes were used for experimental lots of $20 \mathrm{~kg}$., the latter ones for lots of $4 \mathrm{~kg}$. The storage period was about 6 months. Controls were made twice, after about 3 months' storage in the middle of winter, and in spring at the end of storage period. At each control the carrots were weighed, and the diseased carrots were removed. 
In boxes with closed walls rotting of carrots was effectively prevented by Fusarex (cp. the picture 1, p. 86). Only $6-15 \%$ of Fusarex-treated carrots were decayed, while the percentage was $25-71$ for untreated carrots. In the preliminary experiment similar results were obtained with Belvitan $\mathrm{K}$. On the other hand, rotting of carrots was only prevented to a slight extent by peat and sand. In boxes with slits in the walls, Fusarex had a favourable effect at the beginning of storage period, if the carrots were not damaged by maggots of Psila rosae. Towards the end of the storage period rotting was not prevented by Fusarex in any experimental group. The results are given in Table 1, p. 88 .

In experiment 1 in table 1 , rotting was chiefly due to Botrytis sp. In experiments 2 and 4 plenty of Sclerotinia sclerotiorum (LiB.) DE BARY was also found. Each fungus formed plenty of mycelia and sclerotia on the skin of untreated carrots (fig. 1 and 2). If these fungi were found on carrots treated with Fusarex and Belvitan $\mathrm{K}$ they grew beneath the skin and rotted the carrots from within. In experiment 3, rotting was caused by Fusarium avenaceum (FrIES) SACC., Botrytis sp., and Stempylium radicinum (M. Dr. \& E.) NeERG., the first-mentioned being the commonest of them. Fusarex did not seem to have much effect on Fusarium. As the cause of rotting, the other fungi found in this experiment were of slight importance.

Especially towards the end of the storage period, the los: of weight was somewhat greater for untreated than for treated carrots. This was probably chiefly due to easier evaporation of water from diseased carrots as compared to sound ones. Storage with peat at first increased, later prevented the loss of weight. Evidently peat at first absorbed water from the carrots, but later, when it had become wet, it prevented evaporation.

Experiments 1 and 2 show that under certain circumstances rotting is effectively prevented by Fusarex. It has an inhibiting effect at least on Botrytis and Sclerotinia, if treatment is conducted before the beginning of the rotting process. Belvitan $\mathrm{K}$ seems to have a similar quality. In experiment 3 , which was conducted with fairly small experimental lots in open boxes, the effect of Fusarex was of short duration in sound and broken carrots, and in carrots damaged by maggots of Psila rosae it had no effect at all. It is possible that due to open boxes and small storage lots some of the effective ingredient volatilized from Fusarex. This opinion is confirmed by experiments conducted in England on stored potatoes $(1,2)$. It it also probable that the different result of experiment 3 , as compared to experiments 1 and 2 , is due to the different types of fungi found in this experiment. On the other hand, it is easy to understand that Fusarex cannot prevent the rotting of carrots damaged by maggots of Psila rosae. The spores of fungi can namely enter the passages dug by the maggots already during the growth period, and the infection occurs before storage.

Some firms in Helsinki have experimented with Fusarex in carrot storage. Results have been favourable. The following amounts of carrots were treated with Fusarex in the storage sheds by the following firms: Helsingin kaupungin Elintarvikekeskus $128.000 \mathrm{~kg}$., Kesko Oy $10.000 \mathrm{~kg}$., Oy Tuotevälitys $5.000 \mathrm{~kg}$.

In these firms, carrots are usually placed in open bins, in $20-70 \mathrm{~cm}$. thick layers. The temperature in the sheds varies from 2 to $6^{\circ} \mathrm{C} .1-2$ months after the beginning of storage the carrots usually begin to rot so badly that their storage must be interrupted. The progress of the disease can only be prevented to a slight extent by removing the diseased carrots. - The firms have reported that losses by disease have been decidedly lower when carrots have been treated with Fusarex. If they were sound when put in storage, the losses caused by fungi were only $0-5 \%$ even after $3-5$ months' storage period. Losses were, however, greater, if part of the carrots were infected, even if slightly, at the beginning of storage. Fusarex-treated carrots were sold to customers in Helsinki. So far they have not been found to be unhealthy or to have a more unpleasant taste than untreated carrots. The taste experiments conducted at Department of Plant Pathology also showed that Fusarex or Belvitan K did not have injurious effects on the taste of carrots. 